\title{
Single nucleotide polymorphisms in thymic stromal lymphopoietin gene are not associated with allergic rhinitis susceptibility in Chinese subjects
}

Yuan Zhang ${ }^{1,2+}$, Xiaohong Song ${ }^{1,2 \dagger}$, Yanming Zhao ${ }^{1}$, Luo Zhang $^{1,2,4^{*}}$ and Claus Bachert ${ }^{3}$

\begin{abstract}
Background: Thymic stromal lymphopoietin (TSLP) is an epithelial cell-derived cytokine, implicated in the development and progression of allergic diseases. Recent studies have demonstrated significantly increased expression and synthesis of TSLPin nasal mucosa of patients with allergic rhinitis (AR), compared with nonallergic control subjects. Also, there is significant correlation between the level of TSLP mRNA and symptom severity in AR patients. In this study, we investigated whether polymorphisms in the TSLP gene were associated with increased risk of AR in the Chinese population.

Methods: In a candidate gene association study, we tested 11 single nucleotide polymorphisms (SNPS) in the TSLP gene in 368 AR and 325 control adult Han Chinese subjects from Beijing. The 11 SNPs were selected from the Chinese HapMap genotyping dataset to ensure complete genetic coverage. AR was established by questionnaire and clinical examination, and blood was drawn from all subjects for DNA extraction. The PLINK software package was used to perform statistical testing.

Results: In the single-locus analysis of AR risk, no significant differences in allele and genotype frequencies were found between AR and control subjects. Further logistic regression analyses adjusted for age and gender also failed to reveal significant associations between AR and the selected SNPs. Similarly, analysis stratified by gender, and haplotype or diplotype did not reveal any association with AR risk.
\end{abstract}

Conclusion: Although TSLP presents itself as a good candidate for contributing to allergy, this study failed to find an association between specific SNPs in the TSLP gene and AR susceptibility in the Han Chinese population.

Keywords: Allergic rhinitis, Chinese subjects, Genotyping, Thymic stromal lymphopoietin, Single nucleotide polymorphism

\section{Background}

Allergic rhinitis (AR) is an inflammatory disease of the nasal mucosa induced by an immunoglobulin E (IgE)mediated reaction in allergen-sensitized subjects. AR has increased in prevalence over the last decade, in particularly the industrialized nations, and currently affects up to $40 \%$ of the population worldwide [1]. Recent data

\footnotetext{
* Correspondence: dr.luozhang@gmail.com

${ }^{\dagger}$ Equal contributors

'Department of Otolaryngology, Head and Neck Surgery, Beijing Tongren Hospital, Capital Medical University, Beijing 100730, PR China

${ }^{2}$ Key Laboratory of Otolaryngology, Head and Neck Surgery (Ministry of Education of China), Beijing Institute of Otorhinolaryngology, Beijing 100005, PR China

Full list of author information is available at the end of the article
}

from mainland China indicates that the prevalence of self-reported AR in major cities across China is high and ranges between $8.7 \%-24.1 \%$; with around $25 \%$ of all patients suffering from persistent symptoms [2].

There is a plethora of evidence, which suggests that the airway epithelial cells are likely to play an important role in the aetiology of AR, particularly as they represent the first line of defense against inhaled microbes and foreign antigens and are capable of initiating and controlling immune responses by influencing the expression, synthesis and release of a variety of mediators that play a critical role in shaping and driving allergic inflammatory responses $[3,4]$. In this regard, thymic stromal lymphopoietin (TSLP) is an important epithelial cell-derived

\section{Biomed Central}


cytokine, which is expressed in skin, gut, lungs, and thymus [5], and has been referred to as a "master switch" of allergic inflammation at the epithelial cell and dendritic cell interface [6]. Indeed, several studies in humans and mouse models have implicated TSLP in the development and progression of allergic diseases, including atopic dermatitis [7-10], asthma [1113] and AR [14-16]. Moreover, recent studies in Chinese subjects have demonstrated that the expression of TSLPmRNA and/or TSLP protein was significantly increased in the nasal mucosa/epithelia cells of patients with AR compared with the nonallergic control subjects [14,17], and there was significant correlation between the level of TSLP mRNA and symptom severity in AR patients [17].

In view of this evidence, we hypothesized that the TSLP gene is a strong candidate gene, which may influence an individual's risk to develop AR. The aim of this study was therefore to examine whether polymorphisms in the TSLP gene are associated with an individual's susceptibility to develop AR in a Han Chinese cohort.

\section{Methods}

A population-based case-control association study design was used to assess the risk of AR conferred by SNPs in TSLP gene regions.

\section{Study subjects}

Three hundred and sixty-eight adult subjects suffering from AR were recruited from the outpatient clinic of Otolaryngology, Head and Neck Surgery Department at Beijing Tongren Hospital, during February 2010 to November 2010.

All subjects had a history of AR for at least 1 year and fulfilled all of the Allergic Rhinitis and its Impact on Asthma (ARIA) guidelines [18] criteria for AR; including i) presence of persistent or discontinuous symptoms of anterior rhinorrhea, continuous sneezing, nasal obstruction and itching, ii) demonstration of a pale and edematous nasal mucosa, nasal discharge and swollen inferior turbinates by nasal endoscopy, and iii) positive skin prick test (SPT) to a panel of common allergens as shown below (Allergopharma, Reinbeck, Germany) and/or positive serum antigen-specific IgE, measured by the ImmunoCAP 100 system (Pharmacia, Uppsala, Sweden). A diagnosis of AR was further confirmed by the presence of symptoms induced by exposure to an allergen shown to produce a strong positive skin test response.

The tested antigens included house dust mite (HDM) (Der $\mathrm{f}$ and Der $\mathrm{p}$ ); seasonal grass pollens (Giant Ragweed; Mugwort; Lamb's quarers; Humulus; Chenopodium album); animal hair (especially dog and cat); molds (indoor and outdoor mustiness or floricultural environment) and cockroach. A positive SPT result was defined as a wheal greater than or equal to one half of the diameter of the histamine control and at least $3 \mathrm{~mm}$ larger than the diameter of the negative control [19]. Subjects were also considered to be sensitized to allergens when the serum IgE was $\geq 0.35 \mathrm{kU} / \mathrm{l}$.

AR subjects with i) co-morbid asthma, eczema, or any other allergic disease; ii) hypertension, diabetes or other chronic diseases; or iii) tumor in the nasal cavity or any other inflammatory nasal disease were excluded. The diagnosis of asthma was confirmed by a chest physician according to Global Initiative for Asthma (GINA) guidelines [20].

A total of 325 adult healthy control volunteers were also recruited from an ethnically similar local population to determine background population allele frequencies. None of these subjects had a history of allergic or any nasal disease, nor demonstrated any abnormal clinical features in the nasal cavity, or a positive SPT to any of the common allergens as shown above.

All subjects were ethnic Han Chinese, who had lived in the Beijing region, China, over long periods and provided written informed consent prior to entry in the study. The study protocol was approved by the Ethics Committee of Beijing Tongren Hospital and performed in accordance with the guidelines of the World Medical Association's Declaration of Helsinki.

\section{Selection of polymorphisms in the human TSLP gene}

The International Haplotype Mapping (HapMap) (www. hapmap.org) SNP databases were used to select tSNPs in the TSLP gene region. The screened region extended 10 kilobases upstream of the annotated transcription start site and downstream at the end of the last exon in the gene. The tSNPs were selected to extract most genetic information in the region using the $\mathrm{CHB}$ genotyping data from the HapMap database (HapMap data rel 27 Phase II + III, Feb2009) [21]. Genotyping data was obtained for 25tSNPs for TSLP in this dataset and loaded in the Haploview software version 4.2 (http://www.broad.mit.edu/ haploview/haploview-downloads ) [22]. Further selection of the eventual tSNPs to be investigated was made using a pair-wise tagging algorithm [22]; setting the HardyWeinberg $\mathrm{p}$ value, minor allele frequency (MAF), and $\mathrm{r}^{2}$ threshold values at $0.01,0.05$ and 0.8 , respectively. The linkage disequilibrium (LD) pattern of the TSLP gene in the $\mathrm{CHB}$ population exhibited strong LD in several groups of tSNPs $\left(\mathrm{r}^{2}\right.$ greater than or equal to 0.8$)$, indicating that the most common SNPs could be captured by a subset of tagging SNPs [23]. Subsequently, 11TSLP gene SNPs (including rs1545169, rs764917, rs12653736, rs1837253, rs12654933, rs10455025, rs11466741, rs13156086, rs6886755, rs252706 and rs2416259) were selected to represent the entire 25 loci for genotyping. 


\section{Single nucleotide polymorphism genotyping}

DNA was isolated from peripheral blood leukocytes using the DNA Isolation Kit for Mammalian Blood (Roche, Indianapolis, USA), and stored at $4{ }^{\circ} \mathrm{C}$ prior to further investigation within 2 days.Genotyping of the selected SNP was performed using iPLEX chemistry on a matrix-assisted laser desorption/ ionization timeof-flight mass spectrometer (Sequenom, San Diego, California) according to the manufacturer's instructions [24]. The polymerase chain reaction (PCR) and extension primers were designed using MassARRAY Assay Design 4.0 software (Additional file 1: Table S1).

PCR was carried out in standard 384-well plates, using $5 \mu \mathrm{L}$ of a reaction mix comprising $10 \mathrm{ng}$ of genomic DNA, 0.5 units of Taq polymerase (HotStarTaq, Qiagen), $500 \mu \mathrm{mol}$ of each deoxynucleotide triphosphate, and $100 \mathrm{nmol}$ of each primer per well. PCR thermal cycling was carried out in an ABI-9700 instrument (GeneAmpPCR system 9700, ABI, California) for $15 \mathrm{~min}$ at $94^{\circ} \mathrm{C}$, followed by 45 cycles of $20 \mathrm{~s}$ at $94^{\circ} \mathrm{C}, 30 \mathrm{~s}$ at $56^{\circ} \mathrm{C}$, and $60 \mathrm{~s}$ at $72^{\circ} \mathrm{C}$. At the end of cycling, $2 \mu \mathrm{L}$ of a solution containing 0.3 units of shrimp alkaline phosphatase was added to each well and the reaction was incubated at $37^{\circ} \mathrm{C}$ for $20 \mathrm{~min}$, and then at $85^{\circ} \mathrm{C}$ for $5 \mathrm{~min}$ to terminate the reaction.

After adjusting the concentrations of extension primers to equilibrate signal-to-noise ratios, the post-PCR primer extension reaction of the iPLEX assay was carried out in a final volume of $9 \mu \mathrm{L}$ extension reaction mixture containing $0.2 \mu \mathrm{L}$ of termination mix, $0.04 \mu \mathrm{L}$ of DNA polymerase (Sequenom, Inc.), and 625 to $1,250 \mathrm{nmol} / \mathrm{L}$ extension primers. A 200-short-cycle program was used for the iPLEX reaction; involving an initial denaturation by incubation for $30 \mathrm{~s}$ at $94^{\circ} \mathrm{C}$, followed by incubation for $5 \mathrm{~s}$ at $94^{\circ} \mathrm{C}$, five cycles of $5 \mathrm{~s}$ at $52^{\circ} \mathrm{C}$, and $5 \mathrm{~s}$ at $80^{\circ} \mathrm{C}$. Forty additional annealing and extension cycles were looped back to $5 \mathrm{~s}$ at $94^{\circ} \mathrm{C}$, five cycles of $5 \mathrm{~s}$ at $52^{\circ} \mathrm{C}$ and $5 \mathrm{~s}$ at $80^{\circ} \mathrm{C}$, and the final extension was carried out at $72^{\circ} \mathrm{C}$ for $3 \mathrm{~min}$. The final reaction mixture was cooled to $4^{\circ} \mathrm{C}$ and each sample was desalted using $6 \mathrm{mg}$ of clean resin and a dimple plate. The final product was transferred to a 384-well Spectro-CHIP (Sequenom, Inc.), and analyzed in a Compact Mass Spectrometer, using the MassARRAYTyper4.0 Software. The PCR assay was arrayed with two no-template controls and four duplicated samples in each 384-well format as quality controls. All genotyping results were generated and checked by an investigator blinded to the clinical status of the subject from whom the sample was derived.

\section{Statistical analyses}

Data were initially processed for suitability for further statistical evaluation using the Haploview version 4.2software. Hardy-Weinberg equilibrium (HWE) of each SNP was assessed in controls only and a threshold $\mathrm{P}<0.001$ was regarded to indicate deviation from the HWE. The data were filtered further by additionally assessing the minor allele frequency (MAF), non-missing genotype percentage and other criteria in both the AR patients and control subjects; after setting the MAF and non-missing genotype percentage thresholds at $<0.001$ and $<95 \%$, respectively.

Differences in frequencies of the alleles and genotypes between the AR subjects and control subjects were evaluated using the chi-square test and HWE was tested by the chi-square test for goodness of fit according to the web-based program: http://ihg.gsf.de/cgi-bin/hw/hwa1.pl. A P-value of 0.05 was considered significant. Akaike's information criteria (AIC) were used to select the most parsimonious genetic model for each SNP. Odds ratios (ORs) and $95 \%$ confidence intervals (CIs) were calculated by unconditional logistic regression analysis, adjusted for age and gender. Stratification analyses were also performed by variables of interest, such as gender. These analyses were conducted using the STATA statistical package (version 11.0; Stata Corp LP, College Station, TX, USA).

The pair-wise linkage disequilibrium (LD) among the SNPs was examined using Lewontin's standardized coefficient $D^{\prime}$ and LD coefficient $r^{2}$ [25], and haplotype blocks were defined by the method of Gabriel et al. [26] in Haploview 4.2 with default settings. The population as a whole, including AR patients and controls, were utilized in block definition. The HAPLO.STATS package in software language $\mathrm{R}$ developed by Schaidand colleagues [27] (www.mayo.edu/hsr/Sfunc.html) was used for the haplotype analysis and PHASE 2.1 Bayesian algorithm [28] was used to estimate the haplotype frequencies. Haplotypes with a frequency of less than 0.03 were pooled into a combined group and empirical P-values based on 100,000 simulations were computed for the global and individual haplotype score tests. Diplotype (haplotype dosage, an estimate of the number of copies of the haplotype) was the most probable haplotype pair for each individual. Unconditional logistic regression analyses, adjusted for age and gender, were conducted to estimate ORs and 95\% CIs for participants carrying one to two copies versus zero copy of each common haplotype for the dichotomized diplotypes.

The statistical power for the study was calculated using G*Power 2 software (http://www.psycho.uni-duesseldorf. de/aap/projects/gpower/). The statistical power for comparison of AR vs. control was $95.01 \%$, with the sample size of 368 AR patients and 325 controls; the $\alpha$ was 0.05 and the $\beta$ was 0.2 .

\section{Results}

\section{Population characteristics}

The demographic characteristics of the study population are shown in Table 1. Both the AR and control groups 
Table 1 Demographic characteristics of the study population

\begin{tabular}{lll}
\hline Demographic index & AR $(\mathbf{n}=\mathbf{3 6 8})$ & Controls $(\mathbf{n}=\mathbf{3 2 5})$ \\
\hline Age Mean (Range) (years) & $27.08 \pm 0.77(18-71)$ & $36.22 \pm 0.84(18-78)$ \\
Sex, Male/Female, No. (\%) & $227(60.1) / 151(39.9)$ & $175(53.0) / 155(47.0)$ \\
Total lgE Mean (Range), kU/l & $325.35 \pm 31.70(6.9-5000)$ & $69.14 \pm 9.35(2-906)$ \\
\hline
\end{tabular}

$\mathrm{AR}=$ Allergic rhinitis subjects.

were well matched with respect to age, although the AR group consisted of more males (60.05\%) than females (39.95\%). In contrast there were approximately equal numbers of males and females in the control group (53.54\% vs $46.46 \% \mathrm{~m} / \mathrm{f})$. The Pearson Chi-Square test of the ratios for male/female between the control and AR groups showed that these were not significantly different $(P=0.084)$. The mean total serum IgE measurements for $\mathrm{AR}$ and control groups were $325.35 \pm 31.70$ and $69.14 \pm 9.35 \mathrm{IU} / \mathrm{ml}$ respectively.

\section{Individual SNP association analysis}

The initial quality tests for the SNPs in the TSLP gene selected for genotyping demonstrated that two SNPs (rs1545169and rs764917) were not suitable for study, as indicated by significant deviation from the Hardy-Weinberg equilibrium (HWE) threshold of $\mathrm{P}<0.001$ (Table 2). The data for these two loci were therefore excluded from further analyses, and overall a total of nine SNPs (Table 2) from chromosome 5q22.1 were chosen for further assessment. In single-locus analyses for AR risk, the allele frequencies for any of the nine selected tag SNPs were not significantly different between the AR and control subjects $(\mathrm{P}>0.05)$ (Table 2$)$.

Similarly, the genotypes of any of the nine selected SNPs in AR and control were not found to be associated with AR susceptibility (Table 3). Moreover, age and gender adjusted logistic regression analyses revealed that in the codominant-effect model, no significant protective or risk effects against AR were associated with SNPs in TSLP gene, compared with wild-type carriers (Table 3), as assessed by the Akaike's information criteria (AIC). In addition, stratified analyses of AR associations demonstrated no significant associations with any of the selected SNPs among males or females (data not shown).

\section{LD Analysis and Haplotype Block Structure}

Figure 1 shows plots of the pair-wise LD ( $\mathrm{r}^{2}$ and $\mathrm{D}$ ') values for the tag SNPs and LD structures in the selected region of chromosome 5 region (Figure 1-A). Two blocks were identified in AR vs. control subjects in the selected region in chromosome 5; of which block 1 encompassed the $5^{\prime}$ and $3^{\prime}$ regions of the TSLP gene as well as the whole TSLP gene region, whereas block 2 encompassed the $3^{\prime}$ region of the TSLP gene (Figure 1-B).

Table 2 SNPs genotyped for TSLPgene

\begin{tabular}{|c|c|c|c|c|c|c|c|c|c|c|c|}
\hline \multirow{2}{*}{$\begin{array}{l}\text { Gene: } \\
\text { locus and } \\
\text { OMIMNo. }^{\text {a }}\end{array}$} & \multirow[t]{2}{*}{ No. } & \multirow[t]{2}{*}{ SNP_ID } & \multirow{2}{*}{$\begin{array}{l}\text { Chromosome } \\
\text { Position }^{\text {b }}\end{array}$} & \multirow{2}{*}{$\begin{array}{l}\text { Intermarker } \\
\text { distances } \\
\text { (bp) }\end{array}$} & \multirow{2}{*}{$\begin{array}{l}\text { Genic } \\
\text { location }\end{array}$} & \multirow{2}{*}{$\begin{array}{l}\text { Base } \\
\text { Change }\end{array}$} & \multicolumn{3}{|c|}{$\mathrm{MAF}^{\mathrm{c}}$} & \multirow[t]{2}{*}{$P^{f}$} & \multirow{2}{*}{$\begin{array}{l}\text { P value } \\
\text { for HWE } \\
\text { test }\end{array}$} \\
\hline & & & & & & & $\mathrm{NCBI}^{\mathrm{d}}$ & Case $^{\mathrm{e}}$ & Control & & \\
\hline & 1 & rs1545169 & 110427275 & -- & $5^{\prime}$ near gene & $T / G$ & 0.476 & 0.292 & 0.278 & 0.6928 & $<0.0000$ \\
\hline & 2 & rs764917 & 110428406 & 1131 & $5^{\prime}$ near gene & $\mathrm{A} / \mathrm{C}$ & 0.205 & 0.284 & 0.289 & 0.5036 & 0.0004 \\
\hline & 3 & rs12653736 & 110428526 & 120 & $5^{\prime}$ near gene & $\mathrm{G} / \mathrm{T}$ & 0.062 & 0.104 & 0.113 & 0.8689 & 0.6270 \\
\hline & 4 & rs1837253 & 110429771 & 1245 & $5^{\prime}$ near gene & $\mathrm{T} / \mathrm{C}$ & 0.389 & 0.467 & 0.460 & 0.5430 & 0.7337 \\
\hline & 5 & rs12654933 & 110430654 & 883 & $5^{\prime}$ near gene & $C / A$ & 0.244 & 0.154 & 0.144 & 0.7575 & 0.8902 \\
\hline & 6 & rs10455025 & 110432898 & 2244 & $5^{\prime}$ near gene & $\mathrm{A} / \mathrm{C}$ & 0.067 & 0.050 & 0.048 & 0.9790 & 0.3650 \\
\hline \multirow[t]{5}{*}{ TSLP: 5q22.1 } & 7 & rs11466741 & 110436604 & 3706 & Intron 2 & $C / T$ & 0.211 & 0.313 & 0.329 & 0.8127 & 0.2428 \\
\hline & 8 & rs13156086 & 110443368 & 6764 & $3^{\prime}$ near gene & $A / C$ & 0.144 & 0.239 & 0.251 & 0.6890 & 0.7148 \\
\hline & 9 & rs6886755 & 110443500 & 132 & $3^{\prime}$ near gene & $\mathrm{G} / \mathrm{T}$ & 0.089 & 0.077 & 0.073 & 0.9559 & 0.5559 \\
\hline & 10 & rs252706 & 110444759 & 1259 & $3^{\prime}$ near gene & $\mathrm{G} / \mathrm{A}$ & 0.337 & 0.327 & 0.337 & 0.8165 & 0.0635 \\
\hline & 11 & rs2416259 & 110447641 & 2882 & $3^{\prime}$ near gene & $\mathrm{T} / \mathrm{C}$ & 0.411 & 0.369 & 0.366 & 0.6565 & 0.1416 \\
\hline
\end{tabular}

a. OMIM, Online Mendelian Inheritance in Man (http://www.ncbi.nlm.nih.gov/Omim).

b. SNP position in Chromosome 5 in the NCBIdbSNP database (http://www.ncbi.nlm.nih.gov/SNP).

c. MAF, minor allele frequency.

d. MAF for Chinese in the NCBIdb SNPs database.

e. allergic rhinitis subjects.

f. $P$ value for difference in allele distributions between allergic rhinitis and control subjects.

g. HWE, Hardy-Weinberg equilibrium. 
Table 3 Genotype frequencies of 9 tag SNPs among AR and control subjects, and their associations with AR risk

\begin{tabular}{|c|c|c|c|c|c|c|c|c|}
\hline \multirow[t]{2}{*}{ SNP ID } & \multirow[t]{2}{*}{ Genotype } & \multicolumn{2}{|c|}{ AR subjects } & \multicolumn{2}{|c|}{ Control subjects } & \multirow{2}{*}{$\begin{array}{c}P \\
(2 \mathrm{df})^{\mathrm{a}}\end{array}$} & \multicolumn{2}{|c|}{ Logistic regression } \\
\hline & & No. & Frequency & No. & Frequency & & OR $(95 \% \mathrm{Cl})$ & $\mathrm{P}^{\mathbf{b}}$ \\
\hline \multirow[t]{3}{*}{ rs12653736 } & GG & 290 & $79.89 \%$ & 255 & $78.95 \%$ & 0.852 & 1.00 (referent) & \\
\hline & GT & 66 & $18.18 \%$ & 63 & $19.50 \%$ & & $0.999(0.667-1.496)$ & 0.996 \\
\hline & $\pi$ & 7 & $1.93 \%$ & 5 & $1.55 \%$ & & $1.073(0.322-3.572)$ & 0.909 \\
\hline \multirow[t]{3}{*}{ rs1837253 } & $\Pi$ & 98 & $26.85 \%$ & 90 & $28.66 \%$ & 0.828 & 1.00 (referent) & \\
\hline & $\mathrm{TC}$ & 186 & $50.96 \%$ & 159 & $50.64 \%$ & & $1.043(0.719-1.514)$ & 0.823 \\
\hline & $\mathrm{CC}$ & 81 & $22.19 \%$ & 65 & $20.70 \%$ & & $1.078(0.686-1.696)$ & 0.744 \\
\hline \multirow[t]{3}{*}{ rs12654933 } & $\mathrm{CC}$ & 269 & $73.30 \%$ & 237 & $73.37 \%$ & 0.659 & 1.00 (referent) & \\
\hline & CA & 86 & $23.43 \%$ & 79 & $24.46 \%$ & & $1.012(0.701-1.463)$ & 0.948 \\
\hline & $\mathrm{AA}$ & 12 & $3.27 \%$ & 7 & $2.17 \%$ & & $1.151(0.429-3.092)$ & 0.780 \\
\hline \multirow[t]{3}{*}{ rs10455025 } & AA & 333 & $90.74 \%$ & 292 & $90.40 \%$ & 0.622 & 1.00 (referent) & \\
\hline & $A C$ & 33 & $8.99 \%$ & 31 & $9.60 \%$ & & $0.867(0.503-1.492)$ & 0.605 \\
\hline & $\mathrm{CC}$ & 1 & $0.27 \%$ & 0 & $0.00 \%$ & & $N A^{c}$ & $N A^{c}$ \\
\hline \multirow[t]{3}{*}{ rs11466741 } & $\mathrm{CC}$ & 134 & $46.69 \%$ & 112 & $46.67 \%$ & 0.879 & 1.00 (referent) & \\
\hline & $\mathrm{CT}$ & 121 & $42.16 \%$ & 98 & $40.83 \%$ & & $0.993(0.675-1.461)$ & 0.972 \\
\hline & $\pi$ & 32 & $11.15 \%$ & 30 & $12.50 \%$ & & $0.816(0.454-1.469)$ & 0.498 \\
\hline \multirow[t]{3}{*}{ rs13156086 } & AA & 198 & $58.24 \%$ & 169 & $56.52 \%$ & 0.909 & 1.00 (referent) & \\
\hline & $A C$ & 120 & $35.29 \%$ & 110 & $36.79 \%$ & & $0.903(0.639-1.277)$ & 0.564 \\
\hline & $\mathrm{CC}$ & 22 & $6.47 \%$ & 20 & $6.69 \%$ & & $0.826(0.423-1.613)$ & 0.576 \\
\hline \multirow[t]{3}{*}{ rs6886755 } & GG & 317 & $86.38 \%$ & 276 & $85.71 \%$ & 0.624 & 1.00 (referent) & \\
\hline & GT & 47 & $12.81 \%$ & 45 & $13.98 \%$ & & $0.793(0.501-1.256)$ & 0.323 \\
\hline & $\pi$ & 3 & $0.82 \%$ & 1 & $0.31 \%$ & & $2.535(0.255-25.235)$ & 0.428 \\
\hline \multirow[t]{3}{*}{ rs252706 } & GG & 163 & $44.54 \%$ & 149 & $46.27 \%$ & 0.831 & 1.00 (referent) & \\
\hline & GA & 155 & $42.35 \%$ & 129 & $40.06 \%$ & & $1.174(0.837-1.646)$ & 0.353 \\
\hline & $\mathrm{AA}$ & 48 & $13.11 \%$ & 44 & $13.66 \%$ & & $1.120(0.684-1.832)$ & 0.653 \\
\hline \multirow[t]{3}{*}{ rs2416259 } & $\pi$ & 139 & $38.08 \%$ & 126 & $42.14 \%$ & 0.335 & 1.00 (referent) & \\
\hline & $\mathrm{TC}$ & 176 & $48.22 \%$ & 127 & $42.47 \%$ & & 1.361 (0.960-1.928) & 0.083 \\
\hline & $\mathrm{CC}$ & 50 & $13.70 \%$ & 46 & $15.38 \%$ & & $1.122(0.689-1.828)$ & 0.644 \\
\hline
\end{tabular}

$\mathrm{AR}=$ Allergic rhinitis.

a. Global P values [2 degrees of freedom (df)]: genotype frequencies in AR and control subjects were compared using a $X^{2}$ test with 2 df.

b. $P$ values from unconditional logistic regression analyses, adjusted for age and gender.

c. NA, not available because of the rarity of genotype.

\section{Haplotype analysis}

Table 4 summarizes the associations between frequencies of the haplotypes in blocks $r$ rs12654933rs11466741-rs13156086 and rs6886755-rs252706 and the risk of AR. None of the haplotypes investigated was found to be associated with increased risk of AR in the cohort studied. Likewise, no association was found between the diplotypes in the two blocks of AR and AR risk (Table 5).

\section{Discussion}

In this study, we aimed to evaluate the contribution of SNPs in the TSLP gene towards AR susceptibility in Han Chinese subjects by employing a population-based casecontrol association analysis.Our study demonstrated that the allele frequencies for none of the nine tag SNPsselected for AR risk assessment were significantly different between patients with AR and control subjects. Similarly, no differences were found between the AR patients and control subjects for either the genotype distributions of the selected SNPs or the haplotype frequencies. Overall, these findings suggest that although the TSLP gene presents itself as a good candidate involved in the development of allergy, this gene is unlikely to be associated with increased susceptibility to AR in Han Chinese subjects.

The TSLP gene is located on human chromosome $5 \mathrm{q} 22$, near the gene cluster encoding $\mathrm{T}$ helper (Th) 2 cytokines [29,30], and plays a critical role in Th2 cell differentiation [31]. Association studies of allergy related phenotypes using genetic polymorphisms have been 


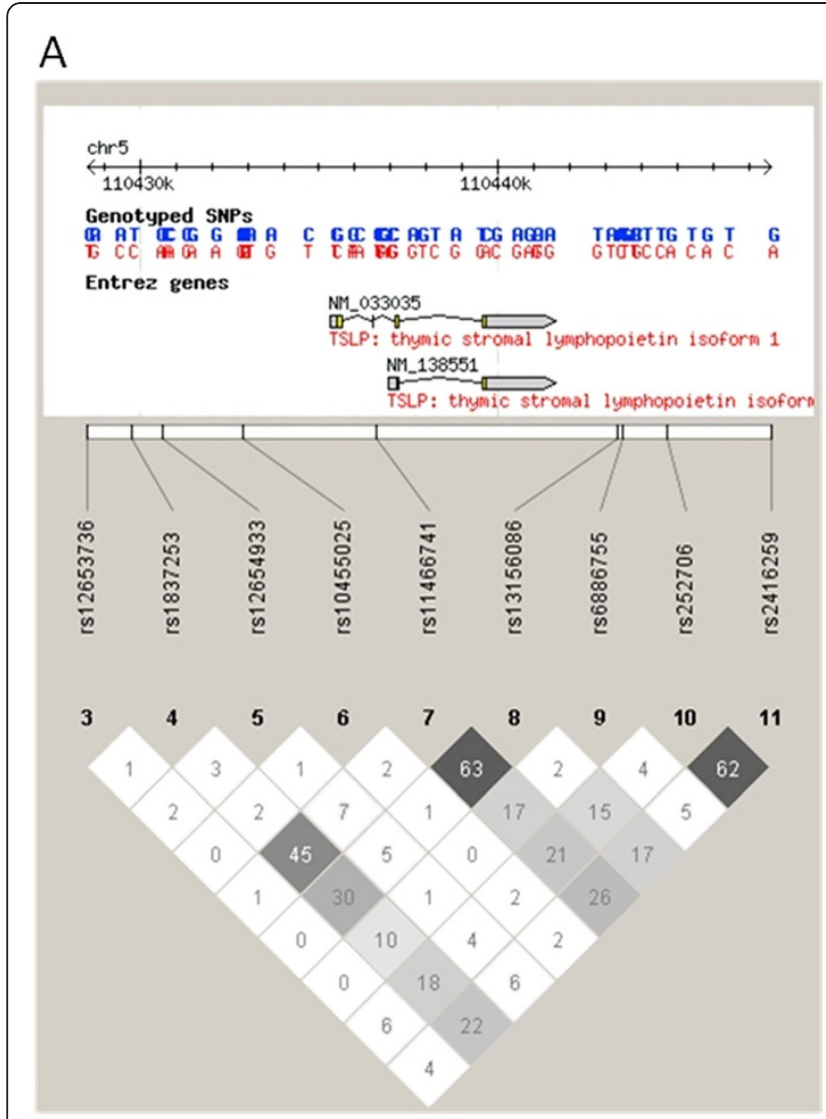

B

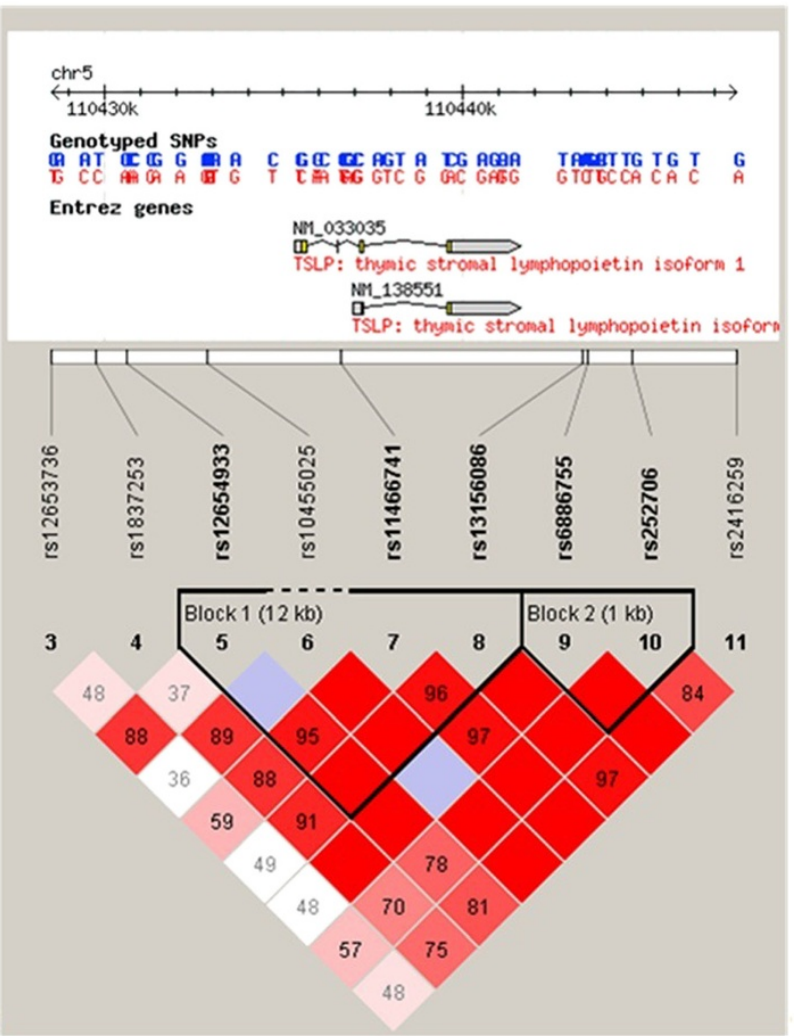

Figure 1 Graphical representation of the SNP locations and LD structure of the candidate gene. Each figure was composed of chromosome scale (the top line with even division), the transcription string (the thick bars represent exon (yellow) or UTR (blue), the thin lines represent intron), SNP scale (the hollow bar with scales representing SNPs location), and graphic of LD (black-and-white) or block definition (flammulated). The measure of $L D\left(D^{\prime}\right)$ among all possible pairs of SNPs is shown graphically according to the shade of color (A), where white represents very low $D^{\prime}$ and dark represents very high $D^{\prime}$. The numbers in squares are $D^{\prime}$ values $\left(D^{\prime} \times 100\right)$. The measure of $L D\left(r^{2}\right)$ among all possible pairs of SNPs is shown graphically according to the shade of color (B), where white represents very low $r^{2}$ and scarlet represents very high $r^{2}$. The numbers in squares are $r^{2}$ values $\left(r^{2} \times 100\right)$.

performed in different populations [32]; with some recent studies showing possible roles of human genetic polymorphisms of the TSLP gene in allergic diseases. One study by Harada and colleagues [33] demonstrated that the SNP rs3806933 in the promoter region of TSLP created a binding site for the transcription factor activating protein (AP)-1, and in vitro enhanced AP-1 binding to the regulatory element. In a more recent study these authors demonstrated that TSLP gene promoter polymorphisms (rs3806933 and rs2289276) were significantly associated with disease susceptibility in both childhood atopic and adult asthma [33]. Similarly, Liu and colleagues [34] demonstrated that one particular variant of TSLP (rs1898671) contributed to asthma susceptibility in admixed urban populations and that the risk of asthma was significantly increased in ex-smokers; suggesting gene and environment interaction. In contrast, a large study from Canada demonstrated that variant rs1837253, which is $5.7 \mathrm{~kb}$ upstream of the transcription start site of the TSLP gene, was associated with protection from asthma, atopic asthma, and airway hyperresponsiveness [35]. More recently, a genome-wide association study in a Japanese population-based cohort of adult asthma utilizing fine mapping analysis of the region on chromosome 5q22 using 13 tag SNPs showed that rs1837253 represented an associated LD block spanning $88 \mathrm{~kb}$ that included two genes, TSLP and WDR36. The authors further concluded that TSLP was the most plausible susceptibility gene in this locus [36]. Similarly, a large consortium-based genome-wide study has demonstrated significant association between asthma and several other SNPs [37]. However, with respect to the association between TSLP polymorphisms and AR, the study by Bunyavanich and colleagues [16] indicated that TSLPSNP rs1837253 was associated with reduced odds for AR in boys with asthma. In the present study, we selected the representative tag SNPs in and near the TSLP gene region and the SNPs confirmed to be the 
Table 4 Associations between common haplotypes near TSLP gene and AR risk

\begin{tabular}{|c|c|c|c|c|c|c|c|c|c|c|}
\hline \multirow[t]{2}{*}{ Block } & \multicolumn{2}{|c|}{$\begin{array}{c}\text { AR } \\
\text { subjects }\end{array}$} & \multicolumn{2}{|c|}{$\begin{array}{c}\text { Control } \\
\text { subjects }\end{array}$} & \multirow[t]{2}{*}{$P^{a}$} & \multirow[t]{2}{*}{$P_{\text {sim }}^{b}$} & \multirow[t]{2}{*}{ Hap. Score ${ }^{c}$} & \multicolumn{2}{|c|}{ Logistic regression } & \multirow[t]{2}{*}{ Global score test $^{f}$} \\
\hline & No. & Frequency & No. & Frequency & & & & OR $(95 \% \mathrm{Cl})$ & $P^{d}$ & \\
\hline \multicolumn{11}{|c|}{ Block1: rs12654933-rs11466741-rs13156086 } \\
\hline CCA & 382 & $52.10 \%$ & 339 & $52.30 \%$ & 0.9211 & 0.6622 & 0.44067 & 1.00 (referent) & & \multirow{4}{*}{$\begin{array}{c}\text { Global-stat }=0.49867 \\
d f=4, p-v a l=0.97363 \\
P_{\text {sim }}^{b}=0.97596\end{array}$} \\
\hline CTC & 180.3 & $24.60 \%$ & 165.1 & $25.50 \%$ & 0.6940 & 0.5274 & -0.63567 & $0.933(0.716-1.217)$ & 0.610 & \\
\hline ACA & 109 & $14.90 \%$ & 91.5 & $14.10 \%$ & 0.7014 & 0.80357 & 0.25053 & $1.029(0.743-1.426)$ & 0.863 & \\
\hline CTA & 56.5 & $7.70 \%$ & 48.4 & $7.50 \%$ & 0.8739 & 0.83692 & -0.20715 & $1.002(0.604-1.664)$ & 0.993 & \\
\hline Others & 5.1 & $0.70 \%$ & 3.9 & $0.60 \%$ & $N A^{e}$ & $N A^{e}$ & $N A^{e}$ & $N A^{e}$ & $N A^{e}$ & \\
\hline \multicolumn{11}{|c|}{ Block2: rs6886755-rs252706 } \\
\hline GG & 430.8 & $58.50 \%$ & 383.1 & $58.90 \%$ & 0.8761 & 0.70783 & -0.37559 & 1.00 (referent) & & \multirow{3}{*}{$\begin{array}{c}\text { Global-stat }=0.71243 \\
d f=2, p-v a l=0.70032 \\
P_{\text {sim }}^{b}=0.70097\end{array}$} \\
\hline GA & 252.1 & $34.30 \%$ & 219.2 & $33.70 \%$ & 0.8355 & 0.4783 & 0.70725 & $1.073(0.845-1.362)$ & 0.563 & \\
\hline $\mathrm{TG}$ & 53.1 & $7.20 \%$ & 47.7 & $7.30 \%$ & 0.9336 & 0.55034 & -0.60092 & $0.913(0.592-1.408)$ & 0.681 & \\
\hline
\end{tabular}

$\mathrm{AR}=$ Allergic rhinitis.

a. $P$ value for difference in haplotype frequency between AR and control subjects.

b. Generated by permutation test with 100,000 times simulation.

c. A positive (or negative) score for a particular haplotype would have suggested that the haplotype was associated with increased (or decreased) risk of allergic rhinitis.

d. $P$ values from unconditional logistic regression analyses, adjusted for age and gender.

e. NA, not available because of the rarity of genotype.

f. df, degrees of freedom.

candidate locus associated with allergy in previous studies. In the present study, rs1898671 and rs3806933 were substituted for rs10455025 and rs12110124 in terms of the $r^{2}$ value $(>0.8)$, but despite the inclusion of these main described TSLP variants (rs1837253, rs1898671 and rs3806933) in the adult Han Chinese population, we were not able to demonstrate any significant association between these variants and AR susceptibility, similar to that shown by Bunyavanich and colleagues [16]. However, unlike the study of Bunyavanich and colleagues [16] which investigated individuals with comorbid AR and asthma, a major strength of our study is that subjects with AR and asthma were excluded and all subjects in this study only had AR. This is of particular relevance because up to $80 \%$ of asthmatics have AR and as noted from several studies described above, TSLP is a well replicated asthma susceptibility gene. Thus, it is possible that the lack of an association between the TSLP gene and AR susceptibility noted in our study is an accurate reflection of the real-life situation, because the TSLP gene is associated with asthma but not AR.

It is of interest that there is evidence which suggests that gender might modify the role of TSLP in asthma. Transgenic expression of TSLP in mice leads to

Table 5 Diplotype analysis of common haplotypes near TSLP gene with AR risk

\begin{tabular}{|c|c|c|c|c|c|c|c|c|c|}
\hline \multirow[t]{2}{*}{ Block } & \multicolumn{2}{|c|}{ 0-copy } & \multicolumn{3}{|c|}{ 1-copy logistic regression } & \multicolumn{3}{|c|}{ 2-copy logistic regression } & \multirow[t]{2}{*}{$P(2 d f)^{b}$} \\
\hline & $\mathrm{AR} / \mathrm{C}$ & OR $(95 \% \mathrm{Cl})$ & $\mathrm{AR} / \mathrm{C}$ & $P^{a}$ & OR $(95 \% \mathrm{Cl})$ & $\mathrm{AR} / \mathrm{C}$ & $P^{a}$ & OR $(95 \% \mathrm{Cl})$ & \\
\hline \multicolumn{10}{|c|}{ Block1: rs12654933-rs11466741-rs13156086 } \\
\hline CCA & $85 / 75$ & 1.000 (referent) & $167 / 144$ & 0.583 & $1.118(0.750-1.667)$ & 116/106 & 0.770 & $1.066(0.695-1.633)$ & 0.947 \\
\hline CTA & $332 / 294$ & 1.000 (referent) & $33 / 30$ & 0.709 & $0.902(0.526-1.548)$ & $3 / 1$ & 0.414 & $2.606(0.262-25.927)$ & 0.676 \\
\hline $\mathrm{CTC}$ & 208/178 & 1.000 (referent) & $136 / 126$ & 0.561 & $0.907(0.653-1.260)$ & $24 / 21$ & 0.739 & $0.896(0.468-1.713)$ & 0.884 \\
\hline ACA & $270 / 240$ & 1.000 (referent) & $86 / 78$ & 0.869 & $1.031(0.714-1.491)$ & $12 / 7$ & 0.763 & $1.164(0.434-3.125)$ & 0.668 \\
\hline \multicolumn{10}{|c|}{ Block2: rs6886755-rs252706 } \\
\hline GG & $67 / 60$ & 1.000 (referent) & $171 / 147$ & 0.888 & $1.032(0.667-1.595)$ & $130 / 118$ & 0.796 & $0.942(0.600-1.480)$ & 0.946 \\
\hline GA & $164 / 149$ & 1.000 (referent) & 156/132 & 0.436 & $1.143(0.817-1.600)$ & $48 / 44$ & 0.678 & $1.110(0.679-1.815)$ & 0.893 \\
\hline TG & $318 / 279$ & 1.000 (referent) & $47 / 45$ & 0.342 & $0.800(0.505-1.267)$ & $3 / 1$ & 0.423 & $2.558(0.257-25.465)$ & 0.629 \\
\hline
\end{tabular}

$\mathrm{AR}=$ Allergic rhinitis subjects; $\mathrm{C}=$ control subjects.

a. $P$ values from unconditional logistic regression analyses, adjusted for age and gender.

b. Global $\mathrm{P}$ values [2 degrees of freedom (df)]: diplotype frequencies in cases and controls were compared using a X2 test with $2 \mathrm{df}$. 
perivascular leukocytic infiltration with prominent eosinophilia, with increased severity noted in female mice compared to malemice [38]. Hunninghake and colleagues [39] reported a sex-specific association between a polymorphism, rs2289276, and serum total IgE in girls in two independent populations. More recently, these authors demonstrated that TSLP polymorphisms were also associated with asthma in a sex-specific fashion [40]. The $\mathrm{T}$ allele of rs1837253 was significantly associated with a reduced risk of asthma in males only, whereas the T allele of rs2289276 was significantly associated with a reduced risk of asthma in females only [40]. However, in stratified analyses of AR associations with gender, no SNPs showed significant associated effects among either male nor female groups in present study.

Despite the possibility that the TSLP gene is generally not associated with risk of AR, as discussed above, it is also possible that the discordance noted between the findings of the present study and previous studies for any associations between TSLP polymorphisms and risk of AR [14,16,17], may be a consequence of difference in study protocols as well as some limitations of the present study. Firstly, we cannot completely exclude the possibility that some of our findings are false negative due to the relative small sample size.It could also be that SNPs in the TSLP gene region confer a relatively small risk of developing AR, which we could not detect. Future efforts to identify TSLPSNPs carrying a smaller TSLP risk will thus require a larger sample size than has been used here. A second consideration is the ethnic variability in SNP frequency known for the gene. It is clear that in this study, we have replicated SNPs associated in other asthmatic populations and the representative tag SNPs in terms of the Hapmap CHB population data, but have not performed extensive fine mapping studies of the gene which might identify other SNPs with increased risk. Moreover, as with many other complex disorders, AR is thought to be the result of a complicated network of numerous susceptibility loci, many of which exert additive or synergistic effects, but have only a small role when considered in isolation [41,42]. Further studies including genes involved in the Th2 pathway are needed in larger cohorts of adult Chinese subjects with AR. However, it is important to note that based on the current study, a particular TSLP variant alone does not show a significant association with the development of AR. Although estimation of TSLP protein in the nasal mucosa of the subjects would undoubtedly have provided further direct information in the elucidation of any association between a TSLP gene variant and susceptibility/development of AR in this cohort, it was unfortunately not possible to accomplish this because of the difficulty in convincing both the AR and control subjects to provide nasal mucosal samples. Moreover, it was also not possible to perform this aspect of the study from the ethical aspects.

\section{Conclusion}

In conclusion, although TSLP presents itself as a good candidate for contributing to allergy, particularly asthma, this study failed to find an association between specific SNPs in the TSLP gene region and AR susceptibility in Han Chinese subjects. However, this finding needs to be confirmed in a larger cohort of patients with only AR.

\section{Additional file}

Additional file 1: Table S1. Primers used in the screening of SNPs by MassArray.

\section{Competing interests}

The authors declare that they have no competing interests.

\section{Authors' contributions}

$Y Z$ participated in the design of the study, carried out the molecular genetic studies and drafted the manuscript. XS conceived of the study and helped to draft the manuscript. $Y Z$ performed the statistical analysis. $L Z$ participated in its design and coordination, conceived of the study and helped to draft the manuscript. CB participated in its design and helped to draft the manuscript. All authors read and approved the final manuscript.

\section{Funding}

This work was supported by grants from the National Science Fund for Distinguished Young Scholars (81025007), National Natural Science Foundation of China (30973282 and 81100706), Beijing Science and Technology Program (Z111107055311040 and KZ200910025008) and Beijing Nova Program (2010B022).

\section{Acknowledgements}

We thank all the clinicians, nurses, technicians and study coordinators for their contributions to the work. We thank BGI Company for genotyping the samples and Yu Zhong for assistance with statistical analyses. We also thank Dr Jagdish Devalia for assistance with editing this manuscript.

\section{Author details}

${ }^{1}$ Department of Otolaryngology, Head and Neck Surgery, Beijing Tongren Hospital, Capital Medical University, Beijing 100730, PR China. ${ }^{2}$ Key Laboratory of Otolaryngology, Head and Neck Surgery (Ministry of Education of China), Beijing Institute of Otorhinolaryngology, Beijing 100005, PR China. ${ }^{3}$ Upper Airways Research Laboratory, Department of Oto-Rhino-Laryngology, Ghent University Hospital, De Pintelaan 185, Ghent 9000, Belgium. ${ }^{4}$ Beijing Institute of Otolaryngology, No. 17, HouGouHuTong, DongCheng District, Beijing 100005, China.

Received: 31 May 2012 Accepted: 11 September 2012 Published: 13 September 2012

\section{References}

1. Bousquet J, Khaltaev N, Cruz AA, Denburg J, Fokkens WJ, Togias A, Zuberbier T, Baena-Cagnani CE, Canonica GW, van Weel C, et al: Allergic Rhinitis and its Impact on Asthma (ARIA) 2008 update (in collaboration with the World Health Organization, GA(2)LEN and AllerGen). Allergy 2008, 63(Suppl 86):8-160.

2. Zhang L, Han D, Huang D, Wu Y, Dong Z, Xu G, Kong W, Bachert C: Prevalence of self-reported allergic rhinitis in eleven major cities in china. Int Arch Allergy Immunol 2009, 149(1):47-57.

3. Mayer AK, Dalpke AH: Regulation of local immunity by airway epithelial cells. Arch Immunol Ther Exp (Warsz) 2007, 55(6):353-362. 
4. Wang Y, Bai C, Li K, Adler KB, Wang X: Role of airway epithelial cells in development of asthma and allergic rhinitis. Respir Med 2008, 102(7):949-955.

5. He R, Geha RS: Thymic stromal lymphopoietin. Ann N Y Acad Sci 2010, 1183:13-24

6. Liu YJ: TSLP in epithelial cell and dendritic cell cross talk. Adv Immunol 2009, 101:1-25.

7. Soumelis V, Reche PA, Kanzler H, Yuan W, Edward G, Homey B, Gilliet M, Ho S, Antonenko S, Lauerma A, et al: Human epithelial cells trigger dendritic cell mediated allergic inflammation by producing TSLP. Nat Immunol 2002, 3(7):673-680

8. He R, Oyoshi MK, Garibyan L, Kumar L, Ziegler SF, Geha RS: TSLP acts on infiltrating effector T cells to drive allergic skin inflammation. Proc Natl Acad Sci U S A 2008, 105(33):11875-11880

9. Briot A, Deraison C, Lacroix M, Bonnart C, Robin A, Besson C, Dubus P, Hovnanian A: Kallikrein 5 induces atopic dermatitis-like lesions through PAR2-mediated thymic stromal lymphopoietin expression in Netherton syndrome. J Exp Med 2009, 206(5):1135-1147.

10. Larson RP, Zimmerli SC, Comeau MR, Itano A, Omori M, Iseki M, Hauser C, Ziegler SF: Dibutyl phthalate-induced thymic stromal lymphopoietin is required for Th2 contact hypersensitivity responses. J Immunol 2010, 184(6):2974-2984.

11. Zhou B, Comeau MR, De Smedt T, Liggitt HD, Dahl ME, Lewis DB, Gyarmati D, Aye T, Campbell DJ, Ziegler SF: Thymic stromal lymphopoietin as a key initiator of allergic airway inflammation in mice. Nat Immunol 2005, 6(10):1047-1053.

12. Headley MB, Zhou B, Shih WX, Aye T, Comeau MR, Ziegler SF: TSLP conditions the lung immune environment for the generation of pathogenic innate and antigen-specific adaptive immune responses. J Immunol 2009, 182(3):1641-1647.

13. Al-Shami A, Spolski R, Kelly J, Keane-Myers A, Leonard WJ: A role for TSLP in the development of inflammation in an asthma model. $J$ Exp Med 2005, 202(6):829-839.

14. Mou Z, Xia J, Tan Y, Wang X, Zhang Y, Zhou B, Li H, Han D: Overexpression of thymic stromal lymphopoietin in allergic rhinitis. Acta Otolaryngol 2009, 129(3):297-301.

15. Miyata M, Hatsushika K, Ando T, Shimokawa N, Ohnuma Y, Katoh R, Suto H, Ogawa H, Masuyama K, Nakao A: Mast cell regulation of epithelial TSLP expression plays an important role in the development of allergic rhinitis. Eur J Immunol 2008, 38(6):1487-1492.

16. Bunyavanich S, Melen E, Wilk JB, Granada M, Soto-Quiros ME, Avila L, LaskySu J, Hunninghake GM, Wickman M, Pershagen G, et al: Thymic stromal lymphopoietin (TSLP) is associated with allergic rhinitis in children with asthma. Clinical and molecular allergy: CMA 2011, 9:1.

17. Zhu DD, Zhu XW, Jiang XD, Dong Z: Thymic stromal lymphopoietin expression is increased in nasal epithelial cells of patients with mugwort pollen sensitive-seasonal allergic rhinitis. Chin Med J 2009, 122(19):2303-2307.

18. Mullol J, Valero A, Alobid I, Bartra J, Navarro AM, Chivato T, Khaltaev N, Bousquet J: Allergic Rhinitis and its Impact on Asthma update (ARIA 2008). The perspective from Spain. J Investig Allergol Clin Immunol 2008, 18(5):327-334

19. Position paper: Allergen standardization and skin tests. The European Academy of Allergology and Clinical Immunology. Allergy 1993, 48(14 Suppl):48-82.

20. Bateman ED, Hurd SS, Barnes PJ, Bousquet J, Drazen JM, FitzGerald M, Gibson P, Ohta K, O'Byrne P, Pedersen SE, et al: Global strategy for asthma management and prevention: GINA executive summary. The European respiratory journal: official journal of the European Society for Clinical Respiratory Physiology 2008, 31(1):143-178.

21. A haplotype map of the human genome. Nature 2005, 437(7063):1299-1320

22. Barrett JC, Fry B, Maller J, Daly MJ: Haploview: analysis and visualization of LD and haplotype maps. Bioinformatics 2005, 21(2):263-265.

23. Carlson CS, Eberle MA, Rieder MJ, Yi Q, Kruglyak L, Nickerson DA: Selecting a maximally informative set of single-nucleotide polymorphisms for association analyses using linkage disequilibrium. Am J Hum Genet 2004, 74(1):106-120.

24. Buetow KH, Edmonson M, MacDonald R, Clifford R, Yip P, Kelley J, Little DP, Strausberg R, Koester $\mathrm{H}$, Cantor $\mathrm{CR}$, et al: High-throughput development and characterization of a genomewide collection of gene-based single nucleotide polymorphism markers by chip-based matrix-assisted laser desorption/ionization time-of-flight mass spectrometry. Proc Natl Acad Sci U S A 2001, 98(2):581-584.

25. Lewontin RC: On measures of gametic disequilibrium. Genetics 1988, 120(3):849-852.

26. Gabriel SB, Schaffner SF, Nguyen H, Moore JM, Roy J, Blumenstiel B, Higgins J, DeFelice M, Lochner A, Faggart M, et al: The structure of haplotype blocks in the human genome. Science 2002, 296(5576):2225-2229.

27. Schaid DJ, Rowland CM, Tines DE, Jacobson RM, Poland GA: Score tests for association between traits and haplotypes when linkage phase is ambiguous. Am J Hum Genet 2002, 70(2):425-434.

28. Stephens M, Donnelly P: A comparison of bayesian methods for haplotype reconstruction from population genotype data. Am J Hum Genet 2003, 73(5):1162-1169.

29. Reche PA, Soumelis V, Gorman DM, Clifford T, Liu M, Travis M, Zurawski SM, Johnston J, Liu YJ, Spits H, et al: Human thymic stromal lymphopoietin preferentially stimulates myeloid cells. J Immunol 2001, 167(1):336-343.

30. Quentmeier H, Drexler HG, Fleckenstein D, Zaborski M, Armstrong A, Sims JE, Lyman SD: Cloning of human thymic stromal lymphopoietin (TSLP) and signaling mechanisms leading to proliferation. Leukemia: official journal of the Leukemia Society of America, Leukemia Research Fund, UK 2001, 15(8):1286-1292.

31. Siracusa MC, Saenz SA, Hill DA, Kim BS, Headley MB, Doering TA, Wherry EJ, Jessup HK, Siegel LA, Kambayashi T, et al: TSLP promotes interleukin3 -independent basophil haematopoiesis and type 2 inflammation. Nature 2011, 477(7363):229-233

32. Vercelli D: Discovering susceptibility genes for asthma and allergy. Nat Rev Immunol 2008, 8(3):169-182.

33. Harada M, Hirota T, Jodo Al, Hitomi Y, Sakashita M, Tsunoda T, Miyagawa T, Doi S, Kameda M, Fujita K, et al: Thymic stromal lymphopoietin gene promoter polymorphisms are associated with susceptibility to bronchial asthma. Am J Respir Cell Mol Biol 2011, 44(6):787-793.

34. Liu M, Rogers L, Cheng Q, Shao Y, Fernandez-Beros ME, Hirschhorn JN, Lyon HN, Gajdos ZK, Vedantam S, Gregersen P, et al: Genetic variants of TSLP and asthma in an admixed urban population. PLoS One 2011, 6(9):e25099.

35. He JQ, Hallstrand TS, Knight D, Chan-Yeung M, Sandford A, Tripp B, Zamar $D$, Bosse $Y$, Kozyrskyj AL, James A, et al: A thymic stromal lymphopoietin gene variant is associated with asthma and airway hyperresponsiveness. J Allergy Clin Immunol 2009, 124(2):222-229.

36. Hirota T, Takahashi A, Kubo M, Tsunoda T, Tomita K, Doi S, Fujita K, Miyatake A, Enomoto T, Miyagawa T, et al: Genome-wide association study identifies three new susceptibility loci for adult asthma in the Japanese population. Nat Genet 2011, 43(9):893-896.

37. Moffatt MF, Gut IG, Demenais F, Strachan DP, Bouzigon E, Heath S, von Mutius E, Farrall M, Lathrop M, Cookson WO: A large-scale, consortiumbased genomewide association study of asthma. N Eng J Med 2010, 363(13):1211-1221

38. Taneda S, Segerer S, Hudkins KL, Cui Y, Wen M, Segerer M, Wener MH, Khairallah CG, Farr AG, Alpers CE: Cryoglobulinemic glomerulonephritis in thymic stromal lymphopoietin transgenic mice. Am J Pathol 2001 159(6):2355-2369.

39. Hunninghake GM, Lasky-Su J, Soto-Quiros ME, Avila L, Liang C, Lake SL, Hudson TJ, Spesny M, Fournier E, Sylvia JS, et al: Sex-stratified linkage analysis identifies a female-specific locus for lgE to cockroach in Costa Ricans. Am J Respir Crit Care Med 2008, 177(8):830-836.

40. Hunninghake GM, Soto-Quiros ME, Avila L, Kim HP, Lasky-Su J, Rafaels N, Ruczinski I, Beaty TH, Mathias RA, Barnes KC, et al: TSLP polymorphisms are associated with asthma in a sex-specific fashion. Allergy 2010, 65(12):1566-1575.

41. Phillips PC: Epistasis-the essential role of gene interactions in the structure and evolution of genetic systems. Nat Rev Genet 2008, 9(11):855-867.

42. Moore JH: A global view of epistasis. Nat Genet 2005, 37(1):13-14.

\section{doi:10.1186/1471-2350-13-79}

Cite this article as: Zhang et al: Single nucleotide polymorphisms in thymic stromal lymphopoietin gene are not associated with allergic rhinitis susceptibility in Chinese subjects. BMC Medical Genetics 2012 13:79. 